\title{
CHN1 wt Allele
}

National Cancer Institute

\section{Source}

National Cancer Institute. CHN1 wt Allele. NCI Thesaurus. Code C97443.

Human CHN1 wild-type allele is located in the vicinity of 2q31.1 and is approximately 206 $\mathrm{kb}$ in length. This allele, which encodes $\mathrm{N}$-chimaerin protein, plays a role in the modulation of signaling. Mutation of the gene is associated with Duane retraction syndrome 2. A translocation of this gene and the TAF15 gene may be associated with extraskeletal myxoid chondrosarcoma. 